Sylwia Zawadzka

Uniwersytet Wrocławski

\title{
Rozwój współpracy minilateralnej Polski z Litwą i Ukrainą na rzecz bezpieczeństwa i modernizacji na przykładzie Trójkąta Lubelskiego
}

$\mathrm{T}$ rójkąt Lubelski, który został zainaugurowany w lipcu 2020 r. jako format trójstronnej współpracy między Polską, Litwą i Ukrainą stanowi istotny etap w rozwoju stosunków między tymi państwami oraz komplementarny wobec istniejących inicjatyw Partnerstwa Wschodniego i Trójmorza fundament przybliżania Ukrainy zarówno do struktur UE i NATO, jak i innych formatów wielostronnej współpracy, w których partycypują państwa europejskie, w tym dawne republiki radzieckie. Charakter nowopowstałej platformy jest jednak szczególny ze względu na równoprawną pozycję wszystkich trzech państw bez względu na ich członkostwo w innych, europejskich czy transatlantyckich strukturach. Od 2014 r. Ukraina i konflikt spowodowany aneksją Krymu są jednymi z kluczowych tematów w debatach nad polityką bezpieczeństwa, agresywną polityką Federacji Rosyjskiej oraz dyskusjach związanych ze wzmocnieniem procesów modernizacyjnych w dawnych republikach ZSRR, które prowadzone są głównie na forum UE i NATO. Ukraina, która nie jest pełnoprawnym członkiem wspomnianych organizacji nie posiada w tej dyskusji wystarczającej podmiotowości, która legitymizowałaby współkształtowanie przez to państwo ich agendy. W związku z tym Polska i Litwa, które połączone są nie tylko wspólnotą interesów, ale i wspólnymi doświadczeniami historycznymi dążyły do wypracowania podstaw dla sformalizowania trójstronnej współpracy. W rezultacie powstał format minilateralny służący pogłębieniu wzajemnych relacji oraz wspieraniu Ukrainy w jej prozachodnich aspiracjach. Państwa Trójkąta Lubelskiego są zgodne co do roli Rosji w destabilizacji systemu światowego bezpieczeństwa, dlatego też trójstronna inicjatywa ma na celu koordynację stanowisk w zakresie przeglądu zasad relacji UE z państwem rosyjskim. Ma to szczególne znaczenie dla Ukrainy, której integralność terytorialna została naruszona przez to państwo, a jednocześnie nie jest ona członkiem UE i nie ma bezpośredniego wpływu na formułowanie jej polityki wobec strony rosyjskiej. 
Pomimo iż wzajemne relacje bilateralne między Polską, Litwą i Ukrainą nie zawsze były dobre, państwa wypracowały podstawy trójstronnej współpracy politycznej i militarnej, których efektem było utworzenie Trójstronnego Zgromadzenia Parlamentarnego, a w 2015 r. powołanie do życia polsko-litewsko-ukraińskiej wielonarodowej brygady LITPOLUKRBRIG, w celu prowadzenia wspólnych ćwiczeń wojskowych i budowania połączonych zdolności operacyjnych. Co więcej, pomimo, iż stosunki dwustronne Ukrainy z Litwą i Polską zmieniały się w zależności od koncepcji polityki zagranicznej poszczególnych rządów, to obydwa państwa starały się angażować w proces umiędzynarodowienia konfliktu ukraińskiego i pomagać stronie ukraińskiej dostarczając jej niezbędnego wsparcia wojskowotechnicznego ${ }^{186}$. Ponadto, Polska określając własną rolę jako adwokata Ukrainy, brała czynny udział $\mathrm{w}$ procesie mediacyjnym $\mathrm{w}$ trakcie kryzysu spowodowanego odrzuceniem Umowy o Stowarzyszeniu z UE. Zarówno Polska, jak i Litwa podkreślają znaczenie ukraińskiego potencjału $\mathrm{w}$ stabilizowaniu europejskiego systemu bezpieczeństwa, a co za tym idzie również rolę tego państwa w zakresie zapewniania bezpieczeństwa w wymiarze globalnym.

W pierwszej części artykułu omówiono główne etapy ewolucji stosunków Polski z Litwą i Ukrainą od rozpadu ZSRR, zwracając szczególną uwagę na kluczowe inicjatywy trójstronne oraz priorytety polskiej polityki zagranicznej i bezpieczeństwa $\mathrm{w}$ wymiarze wschodnim. Następnie przeanalizowano znaczenie Trójkąta Lubelskiego z perspektywy jego wpływu na zacieśnienie relacji między państwami, przede wszystkim $\mathrm{w}$ zakresie współkształtowania europejskiego systemu bezpieczeństwa oraz wdrażania programów na rzecz modernizacji. Celem pracy, w której wykorzystano dwie główne metody badawcze: analizę instytucjonalno-prawną oraz studium przypadku było zdefiniowanie determinantów współpracy polsko-litewsko-ukraińskiej, opartej na koncepcji regionalnego minilateralizmu jako narzędzia wzmacniania roli i pozycji tych państw w Europie Środkowej. Koncepcja regionalnego minilateralizmu, która wyznaczyła teoretyczne ramy badań, została omówiona w kontekście powstałej w 2020 r. inicjatywy Trójkąta Lubelskiego, który traktowany jest w pracy jako instrument soft power, który wykorzystywany ma być w celu modernizacji i wzmacniania stabilności przede wszystkim na Ukrainie. Artykuł opiera się na założeniu, zgodnie z którym Trójkąt jako format minilateralnej współpracy stanowić może bardziej efektywny niż dotychczasowe inicjatywy, instrument wsparcia Ukrainy w integracji ze strukturami transatlantyckimi i strukturami UE. Jednocześnie może stać się jedną z 186 J. Bornio, Lithuania, Poland and Ukraine Inaugurate 'Lublin Triangle', za: https://jamestown.org/program/lithuania-poland-and-ukraine-inaugurate-lublintriangle/?fbclid=IwAR1lsFFCIfSfifCTvl9rma_qK6TVRRxPoyJNrft_cIZ9kHgY945k4D-UOWM (07.08.2020). 
kluczowych platform koordynacji wspólnego stanowiska tych państw na arenie międzynarodowej.

\section{Zarys współpracy Polski z Litwą i Ukrainą po rozpadzie ZSRR}

Polskę, Litwę i Ukrainę łączy wspólnota interesów, strategiczne priorytety wynikające z wyzwań współpracy transgranicznej, a także wspólne stanowisko wobec roli Rosji w systemie globalnego bezpieczeństwa. Te czynniki wpłynęły na rozwój zarówno bilateralnych, jak i trójstronnych relacji między tymi państwami. Szczegółowe omówienie ewolucji tych wielowymiarowych stosunków znacznie wykracza poza merytoryczne ramy artykułu, jednakże w kontekście analizy funkcjonalności nowej inicjatywy Trójkąta Lubelskiego wydaje się konieczne przybliżenie najważniejszych wydarzeń oraz wspólnych projektów (przede wszystkim na rzecz modernizacji i bezpieczeństwa regionu), które zdeterminowały kształt obecnych trójstronnych stosunków między państwami. Uwaga zostanie skoncentrowana przede wszystkim na początkach kształtowania się relacji dwustronnych Polski z partnerami oraz inicjatywach trilateralnych zainicjowanych przed utworzeniem Trójkąta Lubelskiego, który potwierdził wolę otwarcia nowego etapu w stosunkach między trzema europejskimi partnerami.

Relacje Polski z Litwą i Ukrainą po rozpadzie ZSRR zostały uregulowane w traktatach międzypaństwowych, które stanowiły o poszanowaniu ich niepodległości, suwerenności i integralności terytorialnej. Polska prowadziła tzw. politykę dwutorową, która zakładała utrzymywanie stabilnych stosunków ze stroną rosyjską przy jednoczesnej polityce wspierania republik radzieckich w uzyskaniu przez nie pełnej samodzielności. Litwa uchwaliła $A k t$ przywrócenia niepodległości Państwa Litewskiego w 1990 r. jeszcze przed formalnym rozpadem ZSRR. To utrudniało nawiązanie stosunków polsko-litewskich i uznanie przez Polskę jej samodzielności. Deklaracja o przyjaznych stosunkach $i$ dobrosasiedzkiej wspótpracy między Rzeczapospolita Polska a Republika Litewsq została zawarta w 1992 r. i do czasu uchwalenia Traktatu między Rzeczapospolita Polska a Republika Litewska o przyjaznych stosunkach $i$ dobrosąsiedzkiej wspótpracy stanowiła podstawę wzajemnych relacji ${ }^{187}$.

W Traktacie, który otworzył etap budowania strategicznego partnerstwa ustanowiono zasady wzajemnych relacji w poszczególnych dziedzinach, podkreślono znaczenie złożoności wspólnej historii oraz bliskości narodów, a także wskazano, iż współpraca będzie rozwijana

\footnotetext{
${ }^{187}$ W. T. Modzelewski, Dwie dekady stosunków Polski z Litwą - wymiar polityczny, „Środkowoeuropejskie Studia Polityczne" 2012, nr 3, s. 287-291.
} 
na poziomie relacji bilateralnych, jak i w ramach międzynarodowych instytucji ${ }^{188}$. Dla Litwy był to pierwszy taki traktat $\mathrm{z}$ jednym $\mathrm{z}$ czterech państw sąsiednich, natomiast $\mathrm{w}$ przypadku Polski podpisanie Traktatu z Litwą oznaczało zwieńczenie procesu ustanawiania pokojowych relacji i dobrosąsiedzkiej współpracy z krajami sąsiedzkimi ${ }^{189}$.

W deklaracji programowej rządu Litwy utworzonego w 1996 r. współpraca z Polską została zdefiniowana jako jeden $\mathrm{z}$ kluczowych priorytetów. Rząd na Litwie widział W strategicznym partnerstwie z Polską szansę na wsparcie wspólnych wysiłków związanych z aspiracjami obu państw do przystąpienia do struktur euroatlantyckich. W 1997 r. podpisały wspólną deklaracji o pogłębieniu współpracy na rzecz uczestnictwa we Wspólnotach Europejskich i NATO oraz porozumienie o utworzeniu Komitetu Konsultacyjnego przy Prezydentach Polski i Litwy ${ }^{190}$. Powołano wówczas także Radę ds. Współpracy między Rządami RP i RL oraz Polsko-Litewskie Zgromadzenie Poselskie, które stało się wspólnym forum dla dialogu dotyczącego integracji ze strukturami europejskimi i transatlantyckimi, a także odnoszącego się do sytuacji mniejszości narodowych. Struktury te wyznaczyły ramy dialogu politycznego między państwami.

Po przystąpieniu Polski do NATO, stała się ona głównym promotorem państw bałtyckich $\mathrm{w}$ ich drodze do integracji euroatlantyckiej. Z kolei po przystąpieniu obu krajów do UE główną osią współpracy stało się uzgadnianie wspólnego stanowiska na forum tej organizacji (szczególnie w odniesieniu do polityki wschodniej) i wzajemne poparcie dla inicjowanych projektów. Przykładem jest tutaj litewskie poparcie na forum UE polskiego weto w 2006 r. zgłoszonego przeciw propozycji wznowienia rozmów nad nową umową między UE i Rosją. Równolegle do współpracy politycznej, zainicjowano także współpracę dwustronną w dziedzinie obrony, która stała się etapem na drodze rozwoju współpracy trójstronnej, włączającej Ukrainę w organizację wspólnej brygady. W polsko-litewskiej umowie $\mathrm{w}$ dziedzinie obronności podpisanej w 2001 r. określono podstawowe obszary współpracy, takie jak: polityka obronna i strategia; wsparcie logistyczne; operacje wspierania pokoju; rozwijanie interoperacyjności z NATO w narodowych siłach zbrojnych i inne ${ }^{191}$. Z kolei po wstąpieniu Litwy do Sojuszu Północnoatlantyckiego wzmocniono współpracę w ramach międzynarodowych manewrów. Efektem dwustronnej współpracy wojskowej było

\footnotetext{
188 Zob. Traktat między Rzecząpospolitą Polską a Republiką Litewską o przyjaznych stosunkach i dobrosąsiedzkiej współpracy, sporządzony w Wilnie dnia 26 kwietnia 1994 r. (Dz. U. 1995, Nr 15, poz. 71), http://isap.sejm.gov.pl.

${ }^{189}$ W. T. Modzelewski, op. cit., s. 290.

${ }^{190}$ Ibidem, s. 292.

${ }^{191}$ Umowa między Rządem Rzeczypospolitej Polskiej a Rządem Republiki Litewskiej dotycząca współpracy w dziedzinie obronności, sporządzona w Wilnie dnia 5 lutego 2001 r. (MP z dn. 5 lutego 2002 r.).
} 
powstanie polsko-litewskiego batalionu (LITPOLBAT), który osiągnął gotowość bojową w 1999 r., a do 2004 r. był jedyną tego rodzaju formacją, w której partycypował członek NATO oraz państwo aspirujące do członkostwa ${ }^{192}$. Intensyfikacja dwustronnych stosunków nastąpiła ponownie w 2017 r. czego przejawem było zwiększenie częstotliwości obustronnych wizyt przedstawicieli państw w celu wzmocnienia dialogu nad rozwijaniem współpracy gospodarczej i politycznej, wdrażania projektów infrastrukturalnych, a także w zakresie utrzymania pokoju w regionie. W rezultacie w 2019 r. państwa przyjęły deklarację dotyczącą partnerstwa na rzecz bezpieczeństwa ${ }^{193}$.

Odnosząc się do zarysu relacji polsko-ukraińskich warto już na wstępie podkreślić, iż Polska była pierwszym państwem, które uznało niepodległość Ukrainy. Traktat o dobrym sasiedztwie, przyjaznych stosunkach $i$ wspótpracy między państwami został podpisany w 1992 r., natomiast rok później podpisano umowę o współpracy wojskowej. Kolejny etap rozwoju współpracy dwustronnej wyznaczyła deklaracja z 1994 r., która potwierdziła, iż stosunki polsko-ukraińskie maja charakter ścisłego partnerstwa. W tym samym roku podpisano również wspólną deklarację o zasadach i kierunkach współpracy gospodarczej. Deklaracja z 1996 r. będąca efektem oficjalnej wizyty prezydenta Leonida Kuczmy w Polsce stanowiła, iż partnerstwo ma charakter strategiczny. Strony zobowiązały się do wzajemnej pomocy $\mathrm{i}$ poparcia $\mathrm{w}$ dążeniu do integracji $\mathrm{z}$ europejskimi strukturami bezpieczeństwa, a także wspólnego przeciwdziałania wszelkim próbom podziału Europy na strefy wpływów ${ }^{194}$.

W 1997 r. przedstawiciele państw podpisali Wspólne oświadczenie o zgodzie $i$ pojednaniu. Miało ono szczególny wydźwięk, gdyż odnosiło się do uczczenia ofiar konfliktów polsko-ukraińskich, które stały się głównym wyzwaniem dla współpracy obu państw ${ }^{195}$. Warto w tym miejscu zaznaczyć, iż pamięć historyczna oraz sytuacja mniejszości narodowych to kluczowy problem zarówno w stosunkach Polski z Litwą, biorąc pod uwagę spory między państwami na tle praw mniejszości narodowych i możliwości posługiwania się językiem ojczystym, które pogorszyły wzajemny wizerunek obu państw i narodów wśród opinii publicznej, jak i w relacjach Polski z Ukrainą. Pogorszenie stosunków w tym aspekcie nastąpiło w 2009 r. kiedy Sejm Rzeczypospolitej Polskiej przyjął uchwałę stanowiącą o tym,

\footnotetext{
192 W. T. Modzelewski, op. cit., s. 300.

${ }^{193}$ Polska na Litwie, Relacje dwustronne, za: https://www.gov.pl/web/litwa/litwa, (12.08.2020).

${ }^{194}$ Wspólna deklaracja prezydenta Rzeczypospolitej Polskiej i prezydenta Ukrainy o strategicznym partnerstwie, „Biuletyn Ukraiński OSW” 1996, nr 3, s. 17-19.

${ }^{195}$ Polska na Ukrainie, Relacje dwustronne, za: https://www.gov.pl/web/ukraina/relacje-dwustronne (12.08.2020).
} 
iż antypolska akcja ukraińskiego podziemia, która miała miejsce w latach 1943-1944 miała znamiona zbrodni ludobójstwa i charakter czystki etnicznej. W odpowiedzi na to ukraiński prezydent nadał Stepanowi Banderze - przywódcy Organizacji Ukraińskich Nacjonalistów tytuł bohatera ${ }^{196}$. Wspólna historia narodu polskiego i ukraińskiego jest główną przyczyną pogorszenia stosunków między tymi państwami, dlatego polityka oparta na wzmacnianiu kontaktów między społeczeństwami, walka z dezinformacją oraz współpraca naukowców stały się jednymi z kluczowych celów Trójkąta Lubelskiego.

Pomimo sporów wynikających z doświadczeń historycznych obu narodów, Ukraina zawsze zajmowała w koncepcji polityki zagranicznej i koncepcji bezpieczeństwa kluczowe miejsce. Wynikało to z przekonania, iż niepodległe i niezależne państwo ukraińskie przekreśli możliwość dominacji Rosji na obszarze byłego ZSRR. Bezpieczeństwo Polski uzależniano tym samym od postępów w demokratyzacji tego kraju oraz całkowitemu uniezależnieniu się od państwa rosyjskiego na korzyść przybliżenia Ukrainy do struktur euroatlantyckich. Ochłodzenie w relacjach polsko-ukraińskich nastąpiło po rewolucji pomarańczowej, która nie przyniosła oczekiwanych zmian politycznych w kraju. Brak porozumienia elit politycznych doprowadził do rozpadu koalicji i powrotu premiera Janukowycza, który określany był jako polityk prorosyjski ${ }^{197}$.

Mimo pogorszenia stosunków polsko-ukraińskich w latach 2006-2009, Polska podejmowała działania na rzecz przybliżania Ukrainy do struktur europejskich i przeciwdziałania destrukcyjnej i rewizjonistycznej polityce rosyjskiej w regionie Europy Wschodniej, czego rezultatem było zainicjowanie wspólnie $\mathrm{z}$ dyplomacją Szwecji wspomnianego programu Partnerstwa Wschodniego, które na stałe znalazło się w koncepcji polityki wschodniej UE. Ponadto, Polska razem z Niemcami i Francją podjęła pierwsze kroki na rzecz wynegocjowania porozumienia w czasie kryzysu na Ukrainie w 2014 r., co dało wyraz szczególnego poparcia dla sprawy ukraińskiej. Polska opowiedziała się za podtrzymaniem przez UE oferty podpisania Umowy Stowarzyszeniowej w jej pierwotnym brzmieniu, po spełnieniu określonych warunków ${ }^{198}$. Bronisław Komorowski, ówczesny prezydent Polski na posiedzeniu Rady Bezpieczeństwa Narodowego w 2014 r. podkreślił, iż zaangażowanie Polski w rozmowy na forum UE jest konieczne dla wzmocnienia jej wpływu na dalsze wydarzenia mające miejsce na Ukrainie. UE, która traktowana była szczególnie w

196 I. Hurak, Relacje Polski i Ukrainy 2010-2015 - ukraiński punkt widzenia, „Krakowskie Studia Międzynarodowe" 2016, nr 2, s. 181.

${ }^{197}$ K. Fedorowicz, Polityka Polski wobec Rosji, Ukrainy i Białorusi w latach 1989-2010, Poznań 2011, s. 208

${ }^{198}$ A. Kowalczyk, Polityka Polski wobec Ukrainy w 2014 r. - próba bilansu, „Biuletyn Opinie FAE” 2015, nr 3, s. 2-3, za: http://fae.pl/biuletynopiniefaerpukraina2014.pdf (15.08.2020). 
Rosji jako strona tego konfliktu nie brała bezpośredniego udziału w mediacjach między prezydentem Janukowyczem i jego otoczeniem politycznym a opozycją. Kluczową rolę odegrali przedstawiciele resortu spraw zagranicznych państw Trójkąta Weimarskiego, prowadząc rozmowy, które ostatecznie doprowadziły do wypracowania porozumienia ${ }^{199}$.

Polska, Litwa i Ukraina rozwijały również współpracę trójstronną, dzięki której zainaugurowano dwie znaczące inicjatywy w wymiarze politycznym i wojskowym. 13 maja 2005 r. powstało Trójstronne Zgromadzenie Parlamentarne - konsultacyjny organ międzyparlamentarny. Główne cele politycznej struktury dialogu związane są $\mathrm{z}$ opracowaniem zagadnień i projektów, które stanowią przedmiot trójstronnego zainteresowania. Na 10. Sesji Zgromadzenia zatytułowanej Bezpieczeństwo - Rozwój Demokracja. Razem silniejsi, podjęto decyzję o tym, iż w jego skład będzie wchodziło po 12 parlamentarzystów (wcześniej 10). Przewodniczącym narodowej delegacji jest przewodniczący parlamentu danego kraju, a jego zastępcą przewodniczący Komisji Spraw Zagranicznych Parlamentu. Dotychczas w ramach Zgromadzenia funkcjonowały trzy komisje: ds. Rozwoju Handlu i Gospodarki, Współpracy Regionalnej i Lokalnej; ds. Integracji Europejskiej i Euroatlantyckiej Ukrainy; ds. Współpracy Społecznej i Kulturalnej 200. W 2019 r. zadecydowano o utworzeniu kolejnej komisji ds. współpracy w obszarze bezpieczeństwa. Utworzenie Zgromadzenia Parlamentarnego miało przede wszystkim wzmacniać wsparcie dla dążeń Ukrainy do integracji z UE, rozszerzyć współpracę w różnych obszarach oraz poprawić wzajemne relacje między państwami. Ponadto, „dało Polsce i Litwie szansę na zaprezentowanie parlamentarzystom Ukrainy osiągnięć w przygotowaniu ich państw do przystąpienia do UE, delegacji Ukrainy z kolei dało możliwość zapoznania się ze zmianami, które zaszły w tych państwach"201.

Polska, Ukraina i Litwa rozwijają także współpracę w dziedzinie bezpieczeństwa i obronności. Jej efektem było podpisanie w 2014 r. Porozumienia o utworzeniu wielonarodowej brygady (LITPOLUKRBRIG), która uzyskała wstępną gotowość operacyjną w 2016 r., a rok później pełną zdolność operacyjną. Nowy model współpracy zastąpił niejako funkcjonujące wcześniej dwustronne bataliony: polsko-ukraiński Batalion (POLUKRBAT)

\footnotetext{
199 N. Adamczyk, Rola Polski w próbach rozwiązania kryzysu ukraińskiego - od formatu weimarskiego do formatu normandzkiego, „Krakowskie Studia Międzynarodowe” 2016, nr 2, s. 158-159.

${ }^{200}$ IX sesja trójstronnego Zgromadzenia Parlamentarnego Polska-Litwa-Ukraina w Wilnie, za: https:/www.senat.gov.pl/aktualnoscilista/marszalek-i-prezydium/art,11214,ix-sesja-trojstronnegozgromadzenia-parlamentarnego-polska-litwa-ukraina-w-wilnie.html, (05.08.2020).

201 H. Bazhenova, R. Romantsov, J. Olchowski, Zgromadzenie Parlamentarne Sejmu i Senatu RP, Sejmu Republiki Litewskiej i Rady Najwyższej Ukrainy, Instytut Europy Środkowej, Policy Papers 2/2019, za: https://ies.lublin.pl/pub/publikacje/policy-papers/ies-policy-papers-2-2-2019.pdf, s. 72.
} 
istniejący w latach 1998-2010 oraz wspomniany wcześniej litewsko-polski Batalion (LITPOLBAT) rozformowany w 2008 r. Patronem nowej Brygady został Wielki Hetman Konstanty Ostrogski. Porozumienie techniczne z 2015 r. zawiera postanowienia, zgodnie z którymi główną misją Brygady jest prowadzenie wspólnych ćwiczeń, wzmacnianie regionalnej współpracy wojskowej na rzecz utrzymania międzynarodowego pokoju oraz budowanie zdolności do prowadzenia operacji pod auspicjami ONZ, NATO, UE, a także $\mathrm{w}$ ramach tymczasowo tworzonych koalicji ${ }^{202}$.

\section{Priorytety Polski w zakresie współpracy wielostronnej z krajami byłego ZSRR}

Jednym z kluczowych elementów koncepcji polityki zagranicznej Polski po 1989 r. była polityka wobec obszaru dawnego Związku Radzieckiego. W pierwszym etapie, który trwał do 1999 r. priorytetem było zerwanie więzów zależności z komunistycznym totalitaryzmem oraz wspieranie byłych republik radzieckich w odzyskaniu suwerenności. Po uzyskaniu statusu członka NATO, jednym z kluczowych celów stało się wspieranie demokratycznych reform i wolnorynkowej transformacji na obszarze postsowieckim. Rozszerzenie UE o nowe kraje, w tym kraje bałtyckie w 2004 r. oraz ich członkostwo w NATO przyczyniły się do powszechnej opinii, iż bezpieczeństwo Polski jest uzależnione od prozachodniego nastawienia byłych republik ZSRR i dobrych relacji z tymi państwami. Sytuacja zaostrzyła po rosyjskiej agresji na Gruzję i Ukrainę. Odtąd priorytetem polityki zagranicznej Polski w wymiarze wschodnim stała się koncepcja powstrzymywania ekspansjonistycznej i rewizjonistycznej polityki Federacji Rosyjskiej, która zamierzała odbudować swoją strefę wpływów ${ }^{203}$. Konfrontacyjny model prowadzonej przez to państwo polityki potwierdził konieczność redefinicji strategii polskiej polityki wschodniej. Coraz większego znaczenia nabrały działania wielostronne prowadzone w oparciu o struktury NATO oraz UE, a także $w$ ramach mniejszych formatów regionalnych. Przykładem inicjatywy, która stała się jednym z filarów Europejskiej Polityki Sąsiedztwa UE było zainicjowane przez Polskę i Szwecję i ustanowione w 2009 r. Partnerstwo Wschodnie. Celem programu było wzmacnianie prozachodnich tendencji w państwach partnerskich, sprzyjanie procesom modernizacji i wdrażania demokratycznych reform $\mathrm{w}$ tym regionie,

\footnotetext{
${ }^{202}$ Porozumienie techniczne między Ministerstwem Obrony Narodowej Republiki Litewskiej, Ministrem Obrony Narodowej Rzeczypospolitej Polskiej i Ministerstwem Obrony Ukrainy w sprawie szczegółowych aspektów funkcjonowania wspólnej jednostki wojskowej i jej dowództwa, sporządzone we Lwowie dnia 24 lipca $2015 \mathrm{r}$.

203 Raport Polska Polityka Wschodnia, Konferencja Ambasadorów RP, za: https://ec.europa.eu/poland/sites/poland/files/docs/news/raport_polityka_wschodnia_polski.pdf, (07.08.2020), s. $2-3$.
} 
a w dłuższej perspektywie przygotowanie tych państw do stowarzyszenia i członkostwa w Unii ${ }^{204}$.

Aktualnie obowiązujące dokumenty strategiczne z obszaru polityki zagranicznej oraz polityki bezpieczeństwa Polski definiują priorytety $\mathrm{w}$ perspektywie kilku lat również w kontekście polityki wschodniej, która stała się jednym z najważniejszych wymiarów działań zewnętrznych. W Strategii Polskiej Polityki Zagranicznej na lata 2017-2021 już na wstępie podkreślono, iż głównym zagrożeniem dla liberalnego porządku ustanowionego po Zimnej Wojnie i czynnikiem destrukcyjnym europejskiej architektury bezpieczeństwa jest rewizjonistyczna polityka Federacji Rosyjskiej, która „wykorzystując wojnę jako jeden ze środków realizacji celów politycznych w Europie Wschodniej” dąży do odbudowania strefy wpływów na obszarze dawnego ZSRR ${ }^{205}$. Co więcej, prowadzi tam politykę opartą na dezinformacji w celu ożywienia sporów historycznych.

Zgodnie $\mathrm{z}$ treścią dokumentu, aby przeciwdziałanie negatywnym tendencjom było skuteczne musi opierać się zarówno na działaniach dwustronnych, jak i wielostronnych: „w dzisiejszym, złożonym świecie żaden kraj, nawet najpotężniejszy, nie jest w stanie skutecznie prowadzić polityki w pojedynkę. Wynika stąd imperatyw działania wspólnego, zwłaszcza tam, gdzie oparte jest ono na głębokiej wspólnocie interesów osadzonej na mocnym fundamencie solidarności i wartości”"206. W Strategii podkreślono, iż model prowadzonej polityki zagranicznej musi uwzględniać różne wymiary stosunków międzynarodowych i ścisłą kooperację z partnerami i sojusznikami. Aktywna polityka regionalna i poszukiwanie nowych rozwiązań współpracy między wybranymi państwami ma stać się odpowiedzią na dylemat bezpieczeństwa i wyzwania związane przede wszystkim z działaniami Rosji. Ponadto, dokument zawiera zapis, iż losy Polski są nierozerwalnie związane z losami innych narodów Europy Środkowowschodniej. Oznacza to, iż priorytetem w zakresie budowania wspólnoty bezpieczeństwa ma być wzmocniona kooperacja $\mathrm{z}$ państwami tego regionu w celu przeciwdziałania destrukcyjnej roli Rosji.

Z perspektywy Polski, jedynym skutecznym sposobem na długookresową stabilizację obszaru byłego ZSRR jest wdrażanie głębokich reform i projektów modernizacyjnych, odnoszących się do europejskiego modelu rozwojowego. Reformy demokratyczne mają przybliżyć państwa wschodniego sąsiedztwa do struktur UE i NATO, a w dalszych etapach stanowić podstawę negocjacji akcesyjnych. Koncepcja polskiej polityki zagranicznej zakłada,

\footnotetext{
204 Ibidem.

${ }^{205}$ Strategia Polskiej Polityki Zagranicznej 2017-2021, Ministerstwo Spraw Zagranicznych RP, s. 3.

${ }^{206}$ Ibidem, s. 4
} 
iż warunkiem silnego partnerstwa w regionie jest wspólne stanowisko odnoszące się do wyzwań płynących ze środowiska wschodniego sąsiedztwa. Chodzi tutaj przede wszystkim o najbliżej położone kraje członkowskie NATO (kraje współpracujące z Polską w ramach Grupy Wyszehradzkiej, kraje bałtyckie), ale również państwa zorientowane na integrację ze strukturami transatlantyckimi, np. Ukrainę ${ }^{207}$. Jedną $\mathrm{z}$ inicjatyw, które wpisują się $\mathrm{w}$ ten model polityki zagranicznej jest Trójkąt Lubelski zawarty z Litwą i Ukrainą, który ma opierać się na formacie minilateralnych, wzmocnionych relacji społecznych, politycznych czy ekonomicznych. Współpraca ta ma odpowiadać na wyzwania związane z zapewnianiem większej odporności regionalnej na sytuacje kryzysowe i koniecznością rozwoju sieci infrastrukturalnych między państwami bałtyckimi oraz Europy Środkowej ${ }^{208}$. Ma również służyć rozwijaniu polsko-litewsko-ukraińskiej współpracy wojskowej, której podstawą będzie wzmacnianie wspólnej brygady.

Również Strategia Bezpieczeństwa Narodowego wydana w 2020 r. odnosi się do regionalnych powiązań $\mathrm{w}$ celu wzmacniania europejskiego systemu bezpieczeństwa i zapewnienia stabilizacji. Długofalowa koncepcja zadań i rekomendacji zakłada aktywne uczestnictwo Polski $\mathrm{w}$ działaniach UE związanych $\mathrm{z}$ promowaniem reform oraz wzmacnianiem bezpieczeństwa w krajach wschodniego wymiaru Europejskiej Polityki Sąsiedztwa, a także zaangażowaniem na rzecz rozwoju Partnerstwa Wschodniego ${ }^{209}$. Działania dyplomatyczne Polski w ramach Trójkąta Lubelskiego mogą sprzyjać realizacji priorytetu związanego $\mathrm{z}$ zabiegami na rzecz dalszego rozszerzania UE $\mathrm{i}$ wspierania europejskich i transatlantyckich aspiracji państw Europy Wschodniej, gdyż podstawą tej inicjatywy są nie tylko działania związane z umacnianiem niepodległości i integralności Ukrainy, ale również włączanie jej w szersze ramy dialogu politycznego i zbliżenie jej do struktur unijnych. Inny punkt Strategii mówi o pogłębianiu regionalnej współpracy z partnerami kluczowych formatów, takich jak Bukaresztańska Dziewiątka, Grupa Wyszehradzka czy Trójkąt Weimarski, ale stanowi również o potrzebie ustanawiania nowych formatów współpracy $\mathrm{w}$ regionie, które stałyby się platformą kształtowania wspólnego stanowiska, zwłaszcza w kontekście nowych wyzwań i zagrożeń ${ }^{210}$.

Biorąc pod uwagę przeanalizowane dokumenty strategiczne, zarówno koncepcja polityki zagranicznej, jak i polityki bezpieczeństwa państwa polskiego uwzględnia różne

\footnotetext{
${ }^{207}$ Ibidem, s. 10.

${ }^{208}$ Ibidem.

${ }^{209}$ Strategia Bezpieczeństwa Narodowego Rzeczypospolitej Polskiej, Warszawa 2020, s. 24-26.

${ }^{210}$ Ibidem.
} 
poziomy relacji międzynarodowych. Działania bilateralne pozostają jednym z ważniejszych poziomów współpracy, jednakże coraz częściej wykorzystuje się forum struktur wielostronnych, szczególnie w sytuacji, gdy działania dwustronne nie są skuteczne. Wówczas państwa angażują się zarówno w szerokie sieci wzajemnych i sformalizowanych powiązań w wymiarze globalnym, jak i struktury minilateralnej współpracy w regionie, które, mimo iż mają charakter wielostronny, obejmują możliwie najmniejszą liczbę państw. Minilateralizm coraz częściej widoczny w działaniach dyplomatycznych Polski może stać się kluczowym narzędziem jej polityki zagranicznej oraz fundamentem wzmacniania regionalnego i globalnego systemu bezpieczeństwa.

\section{Trójkąt Lubelski jako przykład formatu minilateralnego na rzecz bezpieczeństwa} i modernizacji

Po drugiej wojnie światowej multilateralizm stał się kluczową praktyką koordynowania polityki na arenie międzynarodowej oraz głównym elementem strategii budowania globalnego systemu bezpieczeństwa. Połączenie jak największej liczby państw formalnymi więzami wielostronnej współpracy opartej na wzajemnie respektowanych zasadach miało zapobiec ponownej groźbie użycia siły i zapewnić utrzymanie międzynarodowego pokoju. Taka forma współpracy opierała się przede wszystkim na funkcjonowaniu wielostronnych organizacji międzynarodowych, zrzeszających członków o różnych, często sprzecznych interesach. Organizacja Narodów Zjednoczonych, która powstała w 1945 r. miała służyć wypracowaniu pokojowych narzędzi rozwiązywania konfliktów i ułatwić kształtowanie się nowego, liberalnego ładu międzynarodowego. Jednak brak konsensusu oraz sprzeczność interesów szczególnie wśród stałych członków Rady Bezpieczeństwa dysponujących prawem weta, wzmocniły powszechne opinie o kryzysie multilateralizmu. Zmiany geopolityczne zapoczątkowane rozpadem ZSRR i stopniowe uniezależnianie się republik postradzieckich, a także coraz większa integracja $\mathrm{w}$ ramach struktur Wspólnot Europejskich i NATO doprowadziły do poszukiwania nowych, bardziej efektywnych form współpracy, które miały ograniczać się do wzmocnionej kooperacji regionalnej kilku państw związanych wspólnotą interesów ${ }^{211}$. Koncepcja minilateralizmu, ukształtowana na gruncie krytyki multilateralizmu sensu largo jako forma pośrednia między relacjami dwu i wielostronnymi nabrała szczególnego znaczenia w 2009 r. po opublikowaniu artykułu Moisésa Naíma pt. Minilateralism. The magic number to get real international

${ }^{211}$ D. Jankowski, $W$ stronę skutecznego minilateralizmu $w$ dziedzinie polityki bezpieczeństwa: na przykładzie aktywności Polski w Grupie Wyszehradzkiej, „Bezpieczeństwo Narodowe” 2013, nr 27, s. 7-15. 
action. W artykule zdefiniowano nową formę współpracy jako alternatywę dla nieefektywnego multilateralizmu i wskazano, iż narzędziem skutecznej polityki zagranicznej jest współpraca możliwie jak najmniejszej liczby państw, dzięki której można uzyskać jak największy wpływ na rozwiązanie danego problemu ${ }^{212}$. Istotą minilateralizmu ma być tworzenie inicjatyw współpracy w ramach mniejszej grupy państw, które dążą do realizacji wspólnie określonych celów, głównie związanych z działaniami dyplomatycznymi. Inicjatywy zwane formatami minilateralnymi mogą stanowić $\mathrm{w}$ dalszej perspektywie platformę dla stopniowego rozszerzania współpracy i angażowania w nowe projekty kolejnych państw. W odróżnieniu od multilateralizmu sensu largo, w ramach którego ciężko wypracować jednomyślne stanowisko, inicjatywy minilateralne są bardziej spójne, dynamiczne i funkcjonalne, co przekłada się na większą skuteczność w osiąganiu konsensusu.

Idea minilateralizmu w praktyce realizowana jest od dawna. Przykładem europejskich formatów regionalnych opierających się o taki rodzaj współpracy jest Grupa Wyszehradzka czy Trójkąt Weimarski. Kraje partycypujące w tych inicjatywach należą jednocześnie do szerszych struktur współpracy w ramach UE, jednak minilateralizm stał się narzędziem dla bardziej efektywnego zarządzania polityką w określonym regionie. Rozwiązania przyjęte na poziomie tych formatów mogą stać się podstawą dla określania ogólnej koncepcji polityki europejskiej państw członkowskich, dlatego często szczyty Rady Europejskiej poprzedzane są spotkaniami na szczeblu poszczególnych minilateralnych struktur w celu wypracowania wspólnego stanowiska wobec określonych problemów.

Również kraje postradzieckie zaczęły określać główne kierunki polityki zagranicznej i kształtować coraz bardziej niezależne od Rosji struktury minilateralnej współpracy. 28 lipca 2020 r. w Lublinie ministrowie spraw zagranicznych Polski, Litwy i Ukrainy podpisali deklarację w sprawie utworzenia Trójkąta Lubelskiego - nowego formatu minilateralnego, którego celem ma być pogłębianie współpracy politycznej, ekonomicznej, militarnej i społecznej między państwami. Format stanowi szczególny przykład trójstronnego partnerstwa, gdyż łączy państwa dawnego bloku wschodniego, z których dwa to byłe republiki ZSRR. Co więcej, Polska i Litwa w 2004 r. przystąpiły do Unii Europejskiej, natomiast Ukraina nadal pozostaje poza jej strukturami. Wszystkie państwa łączy jednak wspólnota interesów oraz historyczne i kulturalne więzi między ich narodami. Format jest szansą na włączenie Ukrainy w szersze ramy dialogu politycznego i przybliżenie jej do struktur europejskich i transatlantyckich. Warto przypomnieć, iż Polska była głównym

212 M. Naím, Minilateralism. The magic number to get real international action, za: http://www.foreignpolicy.com/articles/2009/06/18/minilateralism (15.07.2020). 
inicjatorem Partnerstwa Wschodniego jako programu wzmacniającego współpracę między UE a państwami Europy Wschodniej. Zgodnie z wcześniej wskazanymi priorytetami polskiej polityki zagranicznej jednym $\mathrm{z}$ kluczowych elementów koncepcyjnych jej wymiaru wschodniego jest większe zaangażowanie na rzecz wspierania reform i procesów modernizacyjnych na Ukrainie oraz poparcie politycznych aspiracji tego kraju w kontekście jego członkostwa w UE i NATO. W dokumencie ustanawiającym Trójkąt Lubelski podkreślono konieczność wykorzystania przez państwa połączonego potencjału oddziaływania politycznego w debacie nad przyszłością programu Partnerstwa i zwiększenia ich udziału w tworzeniu długookresowych strategii dla jego funkcjonowania w kolejnych latach, tak aby nie stał się on alternatywą dla członkostwa $\mathrm{w} \mathrm{UE}^{213}$. Zgodnie $\mathrm{z}$ treścią dokumentu szczególnie istotne korzyści płynące ze współpracy trójstronnej związane są nie tylko z rozwojem infrastruktury, wzmocnieniem stosunków społeczno-gospodarczych czy koordynacji działań w zakresie bezpieczeństwa. Trójstronna inicjatywa ma wzmocnić pozycję Polski, Litwy i Ukrainy w Europie Środkowej i zwiększyć ich wpływ na kształtowanie bieżącej sytuacji w tym regionie ${ }^{214}$.

Szczególne znaczenie w dokumencie ustanawiającym Trójkąt zostało przypisane wsparciu władz Ukrainy zarówno w realizacji długookresowych celów polityki zagranicznej związanych z przystąpieniem do struktur UE i NATO, jak i w kontekście przeciwstawiania się agresywnej polityce Rosji. Państwa zobowiązały się do większej koordynacji swoich działań na arenie europejskiej. Jednocześnie potępiono aneksję Krymu i wezwano władze Rosji do wycofania wojsk $\mathrm{z}$ terytoriów Ukrainy (regionów donieckiego i ługańskiego) potwierdzając poparcie dla niepodległości, suwerenności i integralności terytorialnej Ukrainy $^{215}$. Postanowienia zawarte w dokumencie jasno wskazują na kolejny etap przybliżania Ukrainy do UE i NATO, jakim powinno być opracowanie Planu Działań na rzecz Członkostwa. Polska, Litwa i Ukraina opowiedziały się za pogłębianiem zarówno bilateralnej, jak i trójstronnej współpracy w dziedzinie bezpieczeństwa i obrony w celu poszerzenia zdolności wojskowych. Państwa zobowiązały się także do podejmowania aktywnych działań na rzecz promocji handlu i inwestycji, zapewniania lepszego dostępu do infrastruktury, opracowania projektów promujących spójność regionu, a także wzmacniania kontaktów między społeczeństwami ${ }^{216}$.

\footnotetext{
${ }^{213}$ Wspólna Deklaracja Ministrów Spraw Zagranicznych Rzeczypospolitej Polskiej, Republiki Litewskiej i Ukrainy w sprawie ustanowienia Trójkąta Lubelskiego, Lublin, 28 lipca 2020 r., s. 1-2.

${ }^{214}$ Ibidem.

${ }^{215}$ Ibidem.

${ }^{216}$ Ibidem.
} 
Mimo, iż nie powołano wspólnych instytucji w ramach Trójkąta Lubelskiego, to główną osią formalnej współpracy będą regularne spotkania szefów dyplomacji oraz konsultacje wyższych urzędników ministerstw spraw zagranicznych. Kolejne postanowienia mówią o powołaniu specjalnych oficerów łącznikowych ${ }^{217}$. Świadczy to o dużym zaangażowaniu przedstawicieli rządów w ustanowienie formalnych procedur nowej inicjatywy i określenia jej szczególnej pozycji w koncepcji polityki zagranicznej. Na spotkaniu w Lublinie, na którym zainaugurowano działalność nowego formatu, stanowisko partycypujących w nim państw zostało przedstawione przez poszczególnych szefów resortów spraw zagranicznych. W ocenie ministra spraw zagranicznych Ukrainy, nowa inicjatywa nie tylko wzmocni pozycję krajów Europy Wschodniej, ale również pozycję Ukrainy jako wiarygodnego i pełnoprawnego członka europejskiej i euroatlantyckiej wspólnoty narodów. Wyraził również nadzieję, iż Trójkąt będzie wspierać zarówno współpracę między trzema inicjatorami, jak i sprzyjać wypracowaniu odpowiednich instrumentów integracji innych państw, które potrzebują ścisłej współpracy z Zachodem ${ }^{218}$. Minister spraw zagranicznych Polski podkreślił krótkookresowe i długookresowe cele nowej inicjatywy zaznaczając przy tym szczególny priorytet związany ze stabilizowaniem sytuacji na Ukrainie i wdrożeniem mechanizmów przeciwdziałania próbom dezinformacji ze strony Rosji, również w kontekście reinterpretacji historii. Zgodnie z wypowiedzią Czaputowicza od sytuacji na Ukrainie zależy bezpieczeństwo Polski i Unii Europejskiej, dlatego należy określić długookresowe plany przybliżania tego państwa do struktur UE i NATO. Poparcie dla aspiracji Ukrainy związanych z członkostwem w tych organizacjach wyraził również szef resortu dyplomacji Litwy minister Linkeviczius, który stwierdził, iż nowa inicjatywa skoncentruje się $\mathrm{w}$ jeszcze większym stopniu niż dotychczasowe przedsięwzięcia na angażowaniu Ukrainy we wspólne operacje wojskowe i stowarzyszenie jej z polityką Wspólnoty Europejskiej ${ }^{219}$.

Ustanowienie Trójkąta Lubelskiego miało istotne znaczenie symboliczne nawiązujące do dziedzictwa Rzeczpospolitej Obojga Narodów, która powstała w 1569 r. na mocy Unii Lubelskiej między Koroną Królestwa Polskiego i Wielkim Księstwem Litewskim. Konferencja prasowa ministrów trzech państw odbyła się przy Pomniku Unii Lubelskiej, co świadczy o dużym znaczeniu pamięci historycznej w relacjach tych państw. Ponadto, symbolika opierająca się na wspólnych doświadczeniach historycznych i dziedzictwie

\footnotetext{
${ }^{217}$ Ibidem

${ }^{218}$ Powstaje „Trójkąt Lubelski”. Nawiązanie do Unii Lubelskiej z $1569 \quad$ r., za: https:/www.defence24.pl/powstaje-trojkat-lubelski-nawiazanie-do-unii-lubelskiej-z-1569-r, (15.08.2020). ${ }^{219}$ Ibidem .
} 
Rzeczpospolitej Obojga Narodów oraz trójstronnej Brygady Litewsko-Polsko-Ukraińskiej LITPOLUKRBRIG mają stanowić wspólne przeciwstawienie się rosyjskiej narracji, przedstawiającej Federację Rosyjską jako jedyną integrującą potęgę w regionie (Bornio, 2020). Wielowymiarowa współpraca w ramach Trójkąta Lubelskiego może przyczynić się do wzmocnienia potencjału i roli uczestniczących w nim państw w zakresie kształtowania systemu bezpieczeństwa i wspierania projektów modernizacyjnych $\mathrm{w}$ dawnych republikach radzieckich. Może stanowić również platformę zintensyfikowanej współpracy z Białorusią, która również ma kluczowe znaczenie dla architektury bezpieczeństwa regionalnego ${ }^{220}$. Co więcej jest to dotychczas jedyny format, w którym Ukraina posiada równy wobec Polski i Litwy status, bez względu na brak członkostwa w UE, NATO czy inicjatywie Trójmorza. Trójkąt może zatem zwiększyć jej potencjał oddziaływania politycznego również na innych forach europejskiej współpracy.

\section{Podsumowanie}

Jednym z kluczowych wymiarów polskiej polityki zagranicznej po 1989 r. był obszar dawnego Związku Radzieckiego. Polska nawiązywała stosunki z republikami postradzieckimi i wspierała ich aspiracje związane $\mathrm{z}$ członkostwem w strukturach europejskich i euroatlantyckich, bowiem od ich prozachodnich dążeń oraz stabilnej sytuacji w regionie uzależniała własne bezpieczeństwo. Początkowo relacje dwustronne stały się głównym elementem koncepcji polityki zagranicznej, jednakże po uzyskaniu członkostwa w UE i NATO coraz częściej zaczęto wdrażać rozwiązania koncepcyjne odnoszące się do działań wielostronnych zarówno na forum tych organizacji, jak i w ramach tworzonych formatów współpracy regionalnej, które ze względu na ograniczoną liczbę partycypujących państw można nazwać formatami minilateralnymi. Ten rodzaj współpracy nie stanowi novum w polityce państw europejskich o czym świadczy funkcjonowanie takich inicjatyw jak Grupa Wyszehradzka czy Trójkąt Weimarski. Stanowił on także podstawę działań dyplomatycznych na Ukrainie w 2014 r. kiedy początkowo mediacje prowadzone były w formacie weimarskim, a następnie formacie normandzkim. Minilateralizm jako narzędzie skutecznej polityki zagranicznej coraz częściej pojawia się w założeniach koncepcyjnych związanych ze wzmacnianiem procesów modernizacyjnych oraz procesów zapewniania bezpieczeństwa na obszarze dawnego ZSRR, a także przybliżania państw tego regionu do struktur europejskich.

${ }^{220}$ J. Bornio, Lithuania, Poland and Ukraine Inaugurate..., op. cit. 
W lipcu 2020 r. Polska, Litwa i Ukraina zainicjowały wspólny format minilateralny, który zakłada wzmocnienie stosunków politycznych, ekonomicznych, wojskowych i społecznych między państwami. Jest on szansą przede wszystkim dla Ukrainy zarówno w wymiarze wewnętrznym, jak i zewnętrznym, gdyż $z$ jednej strony inicjatywa ma koncentrować się na wspieraniu polityczno-gospodarczych przemian na Ukrainie oraz implementacji procedur zapobiegających nadużyciom systemu prawnego, a zatem stanowić kolejny etap demokratyzacji kraju, jak również ma wzmocnić jej pozycję w Europie poprzez osadzenie państwa w szerszych ramach dialogu politycznego. Ukraina nie jest członkiem UE i NATO, jednakże w ramach trójstronnej inicjatywy posiada równy status w stosunku do Polski i Litwy. Poprzez współpracę w ramach tej platformy, która zakłada koordynację wspólnego stanowiska w zakresie polityki europejskiej (szczególnie w wymiarze wschodnim) może zwiększyć swój wpływ na kształtowanie agendy UE w kwestii relacji z Rosją. Będzie on zatem narzędziem miękkiej siły (soft power) oddziaływania politycznego w Europie.

\section{Streszczenie:}

Celem artykułu było zdefiniowanie determinantów współpracy polsko-litewsko-ukraińskiej, opartej na koncepcji regionalnego minilateralizmu, która wyznaczyła teoretyczne ramy badań. Minilateralizm, który stał się jedną z podstawowych form współpracy państw europejskich został omówiony na podstawie istniejących wcześniej struktur współpracy: Trójstronnego Zgromadzenia Parlamentarnego oraz polsko-litewsko-ukraińskiej brygady, jak i w kontekście powstałej w 2020 r. inicjatywy Trójkąta Lubelskiego, która stanowi instrument soft power i ma służyć celom modernizacji i wzmacniania stabilności przede wszystkim na Ukrainie. Artykuł opiera się na założeniu, zgodnie z którym Trójkąt Lubelski jako format minilateralnej współpracy stanowić może bardziej efektywny niż dotychczasowe inicjatywy, instrument wsparcia Ukrainy w integracji ze strukturami transatlantyckimi i strukturami UE, a także element przeciwdziałania destrukcyjnej polityce rosyjskiej wobec regionu dawnego ZSRR, opartej na dezinformacji. Jednocześnie może stać się jedną z kluczowych platform koordynacji wspólnego stanowiska na arenie międzynarodowej.

\section{Słowa kluczowe:}

Trójkąt Lubelski, minilateralizm, Litwa, Ukraina, Polska

\section{Key words:}

Lublin Triangle, minilateralism, Lithuania, Ukraine, Poland 


\section{Bibliografia:}

1. IX sesja trójstronnego Zgromadzenia Parlamentarnego Polska-Litwa-Ukraina w Wilnie, https://www.senat.gov.pl/aktualnoscilista/marszalek-i-prezydium/art,11214,ixsesja-trojstronnego-zgromadzenia-parlamentarnego-polska-litwa-ukraina-wwilnie.html, (05.08.2020).

2. Adamczyk N., Rola Polski w próbach rozwiązania kryzysu ukraińskiego - od formatu weimarskiego do formatu normandzkiego, Krakowskie Studia Międzynarodowe, nr 2.

3. Bazhenova H., Romantsov R., Olchowski J., Zgromadzenie Parlamentarne Sejmu $i$ Senatu RP, Sejmu Republiki Litewskiej i Rady Najwyższej Ukrainy, Instytut Europy Środkowej, Policy Papers 2/2019, https://ies.lublin.pl/pub/publikacje/policypapers/ies-policy-papers-2-2-2019.pdf.

4. Bornio J., Lithuania, Poland and Ukraine Inaugurate 'Lublin Triangle', https://jamestown.org/program/lithuania-poland-and-ukraine-inaugurate-lublintriangle/?fbclid=IwAR11sFFCIfSfifCTv19rma_qK6TVRRxPoyJNrft_cIZ9kHgY945k4 D-UOWM, (07.08.2020).

5. Fedorowicz K., Polityka Polski wobec Rosji, Ukrainy i Białorusi w latach 1989-2010, Wydawnictwo Naukowe UAM, Poznań 2011.

6. Hurak I., Relacje Polski i Ukrainy 2010-2015-ukraiński punkt widzenia, Krakowskie Studia Międzynarodowe, nr 2, 2016.

7. Jankowski D., $W$ strone skutecznego minilateralizmu $w$ dziedzinie polityki bezpieczeństwa: na przykładzie aktywności Polski $w$ Grupie Wyszehradzkiej, Bezpieczeństwo Narodowe, nr 27, 2013.

8. Kowalczyk A., Polityka Polski wobec Ukrainy w 2014 r. - próba bilansu, „Biuletyn Opinie FAE" 2015, nr 3, s. 2-3, http://fae.pl/biuletynopiniefaerpukraina2014.pdf (15.08.2020).

9. Modzelewski W. T., Dwie dekady stosunków Polski z Litwą - wymiar polityczny, Środkowoeuropejskie Studia Polityczne, nr 3, 2012.

10. Naím, M., 2009. Minilateralism. The magic number to get real international action, Foreign Policy, http:/www.foreignpolicy.com/articles/2009/06/18/minilateralism (15.07.2020).

11. Polska na Litwie, Relacje dwustronne, https://www.gov.pl/web/litwa/litwa, (12.08.2020).

12. Porozumienie techniczne między Ministerstwem Obrony Narodowej Republiki Litewskiej, Ministrem Obrony Narodowej Rzeczypospolitej Polskiej i Ministerstwem Obrony Ukrainy w sprawie szczegółowych aspektów funkcjonowania wspólnej jednostki wojskowej i jej dowództwa, sporządzone we Lwowie dnia 24 lipca 2015 r.

13. Powstaje "Trójkąt Lubelski”. Nawiazanie do Unii Lubelskiej z 1569 r., https://www.defence24.pl/powstaje-trojkat-lubelski-nawiazanie-do-unii-lubelskiej-z1569-r, (15.08.2020).

14. Raport Polska Polityka Wschodnia, Konferencja Ambasadorów RP, https://ec.europa.eu/poland/sites/poland/files/docs/news/raport_polityka_wschodnia_p olski.pdf, (07.08.2020).

15. Strategia Bezpieczeństwa Narodowego Rzeczypospolitej Polskiej, Warszawa 2020. 
16. Strategia Polskiej Polityki Zagranicznej 2017-2021, Ministerstwo Spraw Zagranicznych RP.

17. Traktat między Rzecząpospolitą Polską a Republiką Litewską o przyjaznych stosunkach i dobrosąsiedzkiej współpracy, sporządzony w Wilnie dnia 26 kwietnia 1994 r. (Dz. U. 1995, Nr 15, poz. 71), http://isap.sejm.gov.pl.

18. Umowa między Rządem Rzeczypospolitej Polskiej a Rządem Republiki Litewskiej dotycząca współpracy $\mathrm{w}$ dziedzinie obronności, sporządzona $\mathrm{w}$ Wilnie dnia 5 lutego 2001 r. (MP z dn. 5 lutego 2002 r.).

19. Wspólna Deklaracja Ministrów Spraw Zagranicznych Rzeczypospolitej Polskiej, Republiki Litewskiej i Ukrainy w sprawie ustanowienia Trójkąta Lubelskiego, Lublin, 28 lipca $2020 \mathrm{r}$.

20. Wspólna deklaracja prezydenta Rzeczypospolitej Polskiej i prezydenta Ukrainy o strategicznym partnerstwie, „Biuletyn Ukraiński OSW” 1996, nr 3. 